Online: http://journal.uny.ac.id/index.php/jppfa

\title{
THE CONFIGURATIONS OF EDUCATION IN FAMILIES, SCHOOLS, AND COMMUNITIES AND THE RELATIONSHIP WITH THE QUALITY OF EDUCATION AT JUNIOR HIGH SCHOOLS IN BANTUL REGENCY
}

\author{
Setya Raharja ${ }^{1 *}$, Suyata ${ }^{1}$, Siti Partini Suardiman ${ }^{1}$ \\ ${ }^{1}$ Universitas Negeri Yogyakarta \\ ${ }^{1}$ Jl. Colombo No. 1, Depok, Sleman 55281, Yogyakarta, Indonesia \\ * Corresponding Author. Email: setya@uny.ac.id
}

\begin{abstract}
This study aims at finding the configuration pattern in education that exists among families, schools and social community and determining the quality of education which affects the high quality of education. This study implements phenomenological-qualitative approach carried out in three schools in Bantul regency. The respondents of the research were the principals, teachers, students, school committee, and parents. The data were obtained through in-depth interview, observation and documentation study which were analyzed qualitatively. The result of the research shows that the pattern of educational configuration is formed by the variations of school's implementation of responsibilities carried out separately and consecutively in a family, schools and a social community. The quality of education at the level of school system is considered better compared to that of individuals and it also varies based on the school's condition. The pattern of configuration of the educational responsibility aspect is related to the quality of education itself. The pattern does affect the level of the quality of the education if the family, schools and the social community do the responsibility separately, consecutively and consistently without being affected by any distractor.

Keywords: educational configuration, quality of education, education in a family, education at schools, education in the society
\end{abstract}




\section{INTRODUCTION}

Quality remains an important aspect for educators, parents, community, government and business to work together to educate students to meet the challenges of society in the present and future (Arcaro, 1995, p. 56). Most parents choose a quality education, a good learning system and schools which are responsible for the education of their children (Prasetyo, 2010, p. 7). However, it can be said that education cannot fully meet the expectations of the community yet. Therefore, it is necessary to develop strategies to achieve excellence in the education of children through a new paradigm shift in the quality of education (quality oriented) (Syafaruddin, 2002, p. 19).

Since 1999, Indonesia has adopted a policy to improve the quality of education by shifting power from centralized to the decentralized system, which is expected to solve the problems of education in some of the regions or, particularly, at schools (MONE, 2002, p. 10). The policy was strengthened in the Government Regulation No. 19 Year 2005 about National Education Standards, particularly in Education Management Standards (Article 49) (Presiden Republik Indonesia, 2005), which stated that in managing primary and secondary education there should be an implementation of school-based management which is indicated by self-reliance, partnership, participation, openness and accountability.

The implementation of the policy of education quality in Indonesia has not been able to improve the quality of education as expected. The quality of education in Indonesia is still considered low even there is a tendency to get worse (The World Bank, 2005, pp. 1-2). Indonesia still faces problems regarding low quality and relevance of its education system. For example, mathematical ability of junior high school students in Indonesia only ranks 39 th out of 42 countries, while the ability of science only ranked 40th out of 42 countries (Rifai \& Murni, 2010, p. 63). The declining quality of education in Indonesia is also characterized by the decline in education development indices in all aspects. The data from Education for All (EFA) Global Monitoring Report 2011 of UNESCO, indicate that Indonesian educational development index decreased from 65 to rank 69th out of 127 countries, with a value of 0.934 or categorized into me- dium group (Anonim, 2011). This indicates that the quality of education remains unstable and cannot be fully implemented in schools due to the school's commitment to improve the quality of students' personal as well as its educational quality.

However, internally, the quality of education in Indonesia showed an increase regarding the results of National Examination (UN). This is shown by the fact that the number of students who did not pass the exam in 2011 fell sharply compared to the previous year (Anonim, 2010, 2011). The decline in the number of students who do not pass the exam nationally, also occurred in the province of Yogyakarta and Bantul regency. It is indicated by the number of junior high school students who did not pass the exam in $2010(21 \%)$ but in 2011 the number dropped sharply to around $0,8 \%$. These conditions indicate an increase in the competency level of the students particularly dealing with the tested subjects. The data can also highlight that the province of Yogyakarta and Bantul regency struggle to improve the quality of education by keeping the percentage of students who fail in the national examination to be as small as possible. On the contrary, the output character education for junior high school students in the DIY in terms of personal skills and nationalism most students are categorized as low. Meanwhile, in terms of social skills most of the students are categorized high (Zuchdi, 2009, p. 68). The discussion above is an example that there is a dynamic quality of education at the individual level as the supporting aspects of quality and competence including both cognitive and character skills that include personal, social, and nationalism. This phenomenon becomes interesting when the supporting aspects of the quality of education were presented more completely.

The quality of education is not only determined by the learning process as well as the sufficient resources provided by the school, but is also determined by environmental conditions of the family or the community. This means that parents and the community took part in helping the educational success of children. Thus, it can be said that education is a shared responsibility among the school, family, and community or also known as the tripusat of education (MONE, 2007, p. 6; Tirtarahardja \& Sulo, 2005, p. 167). Therefore, parents, teachers, other adults at the school, and the 
social community have an influence on children's educational success.

Meanwhile, in developed countries the schools are mostly established by the social community, so that the quality of the school is thoroughly concerned and the stakeholder can strive to maintain the quality of the school (MONE, 2007, p. 7). This can happen because people believe that school is the best and convincing way in fostering the development and growth of the children, so that they participate actively and optimally in the process of planning, implementation, and oversight of the management as well as the organization of the school.

The involvement and participation of parents and community in education in developing countries, including Indonesia, has not been as optimal as that of in developed countries. Hoyneman and Loxley (MONE, 2007, p. 8) stated that most of the families in developing countries cannot be expected to help and encourage student to learn, which finally lead to time limitation for learning. This is because most parents do not understand the significance of their fundamental role in the education of the children. In fact, Made Pidarta (MONE, 2007, p. 8) describes a condition that occurs in Indonesia, in which parents or community in rural areas with low socioeconomic status, virtually ignored the importance of educational institutions and they hand over the sole responsibility of their children's education to the school.

Education in the family, schools, and communities has different payloads to support the educational success of children. Goodlad (1984, p. 40) explains that there is a shift in the configuration of educational institutions in the US. The configuration of education in the United States between family churches, and schools, plays a specific role related to each other. However, of the three institutions, school is highly marginalized. In the process, the school is held solely as an additional (addon) of what they have learned in the family and the church. Most families teach the children about anything required for a living, while the church is mostly teaching the broader meaning of life (piety). After the American Revolution, the relationship between the houses (families), churches, and schools continue, but the effect is resulted from education both by the schools and the press. In the twentieth century, a shift in the balance of roles between home and school education is characterized by the emergence of bureaucracy in the education system; counseling in schools; family which emphasizes ethnicity, family origins, and the importance of the individual in the family; schools also emphasize the general value of life, and bring more dynamic as well as provide the desired educational balance. The Goodlad's study illustrates that the influence of education in the family, school, and community can shift over time and can result in varying configurations. Each of these configurations directly or indirectly affect the efforts of the school in establishing the quality of education that ultimately have an impact on the quality of the process and the results of the children's education

The dynamics of educational quality and configuration pattern also occurred in education in Indonesia. The quality of education needs to get serious attention both in terms of the process and the results which refers to the demands of the society. Education in family, schools, and social communities must also be adjusted to be able to create an atmosphere of harmonious education in schools, conducive and productive for sustain and improve the quality of education. Such things bring a thought to the need to explore more about education in the family, school, and community as well as the dynamics that occur in the quality of schools in Indonesia.

One of the prioritized developments of education in Indonesia in 2010-2014 was the completion of nine years of basic education quality for all children aged 7-15 years (Anonim, 2011). The completion of nine years of basic education is the national movement compulsory regarding nine-year basic education (9 years of Compulsory Basic Education) which is implemented since 1994 based on Presidential Instruction No. 1 of 1994 (Presiden Republik Indonesia, 1994). The 9 year basic education is mandatory for all Indonesian citizens aged 7-12 years and a shared responsibility between government, parents, and community. The accelerated program under the Instruction No. 5 of 2006 (Presiden Republik Indonesia, 2006) is to increase the Gross Enrolment Ratio (GER) of children aged 13-15 years at least to $95 \%$ by the end of 2008 . In accordance with government policy mentioned above and in the hope to support the implementation of the policy, this study fo- 
cused on primary education, particularly at the level of Junior High School (SMP).

Psychologically, junior high school students between the ages of 13-15 years belong to adolescence or transition period. At this time, the children are at the age of problem, in which the problem will be solved independently and they tend to refuse help from parents or teachers (Hurlock, 1991, pp. 207209). Children are also at the age in which they that may have a view of unfavorable or negative issues. Children tend to view themselves and others as not desirable as it is, so it is known as the child being at unrealistic condition. Such psychology development needs to be facilitated so that they are able to play their role as junior high school students optimally.

Based on the descriptions above, it is necessary to do a more thorough study focusing on the problems dealing with the quality of education and educational configurations between families, schools, and social communities, especially in junior high school. It is considered that the development of education, especially the acceleration of nine-year basic education as well as psychological reasons of the development of junior high school age children will bring consequences regarding the needs of quality education. This research is concentrated in Bantul district of Yogyakarta in regard to the fact that Bantul district committed to education and has a variety of geographic areas of the city, village, beach, in which there are both public and private junior high schools.

Based on the initial survey conducted by researchers (2011) in several secondary schools in Bantul, the information about the condition of the role of parents, school, and community in the education of children, and how the quality of school education in their targeting is obtained. First, the role of parents, schools, and communities in the education of children in some schools show variation both in general and also on each aspect. Second, in determining the target of quality education, the school is to accommodate the interests of various elements, such as: schools, school boards, parents, the community or the community leaders, and also the policy from both local and central government.

It is expected that the findings will give benefits theoretically, practically, and methodologically especially to improve the relationship between the educational institution, parent, and society, as well as the quality of the school. Theoretically, the findings are expected to strengthen and enrich the developmental concept of school concept, concept of socialization and children education, and concept of school quality. Practically, the configuration pattern of education between family, school, and society identified could be a consideration by the policy makers from school level to educational service of district for relational enrichment program and an effort to improve the quality of education at school. Methodologically, it is expected that the findings could enrich the qualitative research methods related to the school in Indonesia especially those using a phenomenological qualitative approach.

The quality of education is the whole characteristic illustration of the educational components as a system representing its ability in fulfilling the subjects' needs and hopes. The quality of education is dynamic which can develop through times and changes of environmental contexts from the student level to educational system, so it has different implications toward each individual, group, or institution (Arcaro, 1995, p. 63; Aspin, Champan, \& Wilkinson, 1994, pp. 44, 71; Danim, 2006, p. 52; Guellali, 2008, p. 132; Pigozzi, 2004, p. 5; Tjiptono \& Diana, 2000, p. 4; UNESCO, 2005, p. 1; Zamroni, 2002, p. 39). The quality of education mentioned in this study is the condition of ten key aspects supporting the quality of education which are grouped into the quality aspect of student's individual level and school's system level (Pigozzi, 2004, p. 5; UNESCO, 2005, pp. 1-3). Regarding the quality of education of the student's individual level can be seen from the five aspects of quality such as the school understands students' conditions, admits students' knowledge and experience, develop the relevance of educational contents, implement various kinds of learning process, and improve the learning environment. The quality of education related to the school system also can be seen from five aspects of quality which are the school creates the framework of legislation, implement good policy, develop administrative and leadership support, provide sufficient source, and measure learning achievement.

This configuration concept of education in this study refers to the term used by 
Goodlad (1984, p. 40) to elaborate the relationship of the educational institution of parents, church, and school in United States of America. Such educational institution includes the parents, school, and society limited by the neighbors, friends in the same age, and mass media. Therefore, the configuration of education in this study is the relationship created by the implementation of the educational responsibility between parents, school, and society including their neighbors, friends in the same age, and mass media. Education will not succeed without the collaboration between parents and society (Decker \& Decker, 2003, p. 49). Similarly, Epstein brought a theory of overlapping spheres of influence stated that students will learn better when their family, teachers, and society admit their shared goal, responsible to the children learning, and be cooperative (Epstein \& Voorhis, 2010, pp. 1-2). That model involves three contexts named home, school, and society related to one another in several educational aspects.

Education at home, school, and society can be found in an ecology theory stated by Urie Bonfenbrenner (1989). This theory states that in the scope of micro system, children grow as a result of socialization and support of their environment such as family, school, or society including friends in the same age, neighbors, and mass media (Bern, 2004, p. 15). Family becomes environment providing assistance, affection, opportunity variety, and a place of basic socialization for the children significantly influence to their development. School is a formal micro system where the children learn their society, reading, writing, arithmetic, history, science, and so on; reinforce the development of various skills and behavior, and motivate the children. Friends in the same age are a general area where the children are not monitored by adults, so they have experiences in the free environments. Neighbors are the main micro system where the children learn by doing. Mass media; such as television, film, video, book, magazine, music, and computer; are not categorized as a micro system stated by Bronfenbrenner as it does not represent small and interactive environment in the mutual interaction. However, mass media are important agents of socialization as micro system, because it is an environment which has a higher possibility for the children to see the past, present, and future, place and equipment, role and it is related to one another, attitude and value, and behavior to be imitated.

The responsibility of education in the family, school, and community can be divided into separated responsibilities, sequenced, and performed together (Cox-Pettersen, 2011, p. 20). Separately, the family is responsible for the media, TV, games, religion, culture, values, discipline, and role in the house; schools accountable for the content aspect of the academic, a role in the school, and discipline in schools; while the society is responsible for the maintenance of public places or public facilities, and law. Sequentially, responsibilities include family which responsible for the health and vaccines, personal health, civic responsibility. Later, in the school, it is continued by health screening, personal health, and participation. Then, in the community, it is continued by aspects of health care in which a citizen is in a democratic society and justice oriented. The shared responsibilities include the educational aspects of social skills, communication, work ethic, nutrition, safety, drug awareness, sex education, physical education, and character education.

\section{RESEARCH METHOD}

This study employed a phenomenological qualitative approach. The research was conducted in 2012-2013, located in three junior high schools in the district of Bantul which were Kretek State Junior High School 2, Imogiri State Junior High 3 and PGRI Junior High School of Kasihan, Bantul.

The subjects of the study included school principals, teachers, students, school boards, and parents who also became informants. The informant was determined based on the consideration of key informants from each school which was with details of one school principal, one teacher, two students (male, female), one school board administrators, and one student's parents, so there were eighteen informants in total.

This research was conducted with the following steps: (1) identification of schools having a special phenomenon in terms of children's education and the quality of education, (2) stabilization of the phenomenon through the initial study, (3) the deepening of educational phenomena in the family, school, and 
society and the quality of education through indepth interviews, observation, and study of documents, (4) the meaning of the phenomenon and making conclusions about the configuration of education and quality of education.

The data obtained in this study were the qualitative data collected through interviews, observation and study of documents, interview, observation guidelines and guidelines of documents studies.

The data were analyzed qualitatively with the steps of organizing data, and coding and reducing the data, classifying the meaning and describing the experience, finding the phenomenon, explaining the essence of the phenomenon and making conclusions.

\section{FINDINGS AND DISCUSSION}

The presentation of the research findings and discussion in this paper was adapted to the formulation of research problems which was begun with the configuration patterns of education and the quality of education in each school, followed by a link between the pattern of educational configuration with the quality of education, and ended with configuration patterns which influenced to the high quality of education.

\section{Configuration of Education and Quality of Education in Kretek State Junior High School 2}

The condition of most families of the students of Kretek State Junior High School 2 could be said to be weak in terms of socioeconomic, which resulted in families' low participation in the school activities for their children's education. This is in line with the Lareau's view (1989) which states that lowincome parents do not actively participate to get involved in school and just trust the schools or teachers (Lazar \& Slostad, 1999, p. 208). However, the education taken place in the family of the students of Kretek State Junior High School 2 suggested that parents have a strong commitment to the education of their children.

Kretek State Junior High School 2 has clear vision, mission, and educational goals, and has a well-prepared working program both for short and long term. Teachers' and employees' resources are fairly enough and they have a high work ethic. Educational facilities are quite adequate. The school has the authority to implement and administer a sport class. These conditions illustrated that the education in this school was handled well. The education process in this school showed that this school has serious attention to the education of their students.

The characteristics of the communities in the region of Kretek State Junior High School 2 are near Parangtritis and Depok Beach. In the area of Depok Beach, it is more regular, especially culinary, free from negative habits; while in Parangtritis Beach, its community is more complex such as there is lodging, and it is not free from negative habits. On the other hand, the control of community is through the congregation (Islamic congregation) i.e. through the recitation in mosques. In the area of Parangtritis Beach, Muslims unite to fight against the things that are less positive, to held Islamic congregation frequently. In addition, the society at the area of Depok Beach was able to control prostitutes, so in the area of Depok Beach can be said truly sterile of such activity.

To examine the implementation of the educational responsibilities undertaken by the family, school, and the community was analyzed with the reference to the views of (CoxPettersen, 2011, p. 20) in which the responsibility is done separately, sequentially, and shared. (1) The responsibility of education which is separated at Kretek State Junior High School 2 can be explained as follows. The family is responsible for civilizing the child to ask permission of parents, themselves, improving the values of the school, especially not coming late, improving discipline of time and to learn, training the child's role by giving them light duties. The school academic contents are delivered through formal education packed in School Based Curriculum with the contents of national content, local content, extracurricular, and self development, training the child's role by giving some duties and responsibilities in their class, and improving children discipline through flag ceremonies, dressed style and the use of mobile phone. In the society, children experience from neighbors or the environment in terms of maintenance of the public facilities through community traditions and parking management in a tourist spot. (2) The responsibility of a sequential education includes three aspects, namely religious education, health, and civic education. Religion and health education 
begins in the family and then continued in the school and community. Another case is for the educational aspects relating to citizenship, it was the most unknown aspect among the other children at school which are through extracurricular activities, student council, as well as disaster response training, then continued in the community through interaction with peers. (3) The aspects of education conducted jointly by the family, school, and community include social skills, physical education, drug awareness and sex education, while the medium education with regard to nutrition, character education, use of media; fostering academic achievement and non-academic; it was only done jointly between families and schools.

The above description showed that the pattern of the configuration of education in Kretek State Junior High School 2 was formed by implementing educational responsibilities in the family, school, and community that included neighbors, peers, electronic mass media (television, mobile phones, and the Internet, either separately, sequentially, or jointly. (1) Separately, families educate their children in terms of discipline, culture, values, and the role of children; schools provide formal education to the charge of academic, discipline, and the role of the student; currently teach children to take a good care of public facilities or public places . (2) Sequentially, family, school, and community provide education related to religion and health of children, while it is special for schools and communities, they introduce the child's life as a citizen. (3) Taken together, families, schools, and communities are responsible for physical education, social skills, awareness of drugs, and sex education, while for aspects of nutrition education, character, use of media; fostering academic and non academic achievement it was only made jointly between families and schools.

The quality of education in Kretek State Junior High School 2 can be grouped into the quality at the level of the individual student and the level of school system by referring to the text of UNESCO (2005, p. 1). The condition of every aspect of quality at the individual level in Kretek State Junior High School 2 is as follows. (1) The school is able to reduce the barriers or difficulties of the students from the reason of poverty and ethnicity, so that the students keep continuing to study. (2) The school can strengthen students' knowledge and experience in the aspects of academic achievement, non-academic, and behavioral students. (3) The school adjusts the content of education that are curricular, extracurricular, national content, local content according to the conditions of students, schools, and the potential of the region. (4) The school implements various creative learning processes with lesson schedules, learning services, model of extra-tutorial lesson, and learning variations. (5) The school can eliminate physical punishment with educating punishment; reduce students' anxiety by providing safe classroom, but the school sanitation facilities does not work quite well. These conditions describe that the aspects of the quality of education at the individual level has been attempted by the students of Kretek State Junior High School 2 optimally through various creations adjusted with the conditions and the ability of the school. However, there is one aspect that is not optimal yet, i.e. improving the learning environment particularly the aspect of the physical environment of the school. The prominent creativity of school and teacher is in terms of understanding the condition of the school students concerned the students who are less fortunate, making the relevance of educational contents through 'situational-innovation', and implementing the learning process with the academic services of the teachers for the students is extra and voluntary both at school and teacher's home.

The quality condition of education in the school level at Kretek Junior High School 2 can be best described as follows. (1) The school issues the regulations which guarantee the students' rights to acquire education appropriately such as; the responsibility of school uniforms should belong to the students or their parents; school gratification should be based on the mechanism of donations; school orientation should be free from harassments which can be done by intensifying the involvement of all school committee and students' parents. (2) Externally, the school regulations are in line with the instructions from the school leader, while internally the regulations can also guarantee all of school stakeholders to be served appropriately, for example the dispensation for deprived students and the academic service book usage. (3) The school administration and leadership is the duty of the school principal supported by teachers and school staffs which are finally in collaboration with the school 
committee and class organization, yet, this relationship must always be maintained in order to develop the inter-relationship among the entire school stakeholders. (4) The school could make ample completion on its infrastructure then makes the effective usage to support teaching and learning process. Besides, it is also provided some funds for any school program. The competent human resources also become parts of school stakeholders who can collect and manage school donation. (5) The school assesses students' learning results through daily exams, mid-term exam, and final exam which are seriously managed by teachers and the school. As a result, it can be inferred that the education quality in the school level system in Kretek Junior High School 2 appears to be optimal in creating regulation scaffolding, the implementation of the regulations, the availability of mechanism resources, and the assessment of students' learning result, though the lack still exists in terms of improving administrative supports and leadership.

\section{The Configuration of Education and the Quality of Education in Imogiri State Junior High School 3}

Most of the families of the students of Imogiri State Junior High School 3 seem to be feeble in terms of socio-economic with low educational background as well. The condition affects their behavior towards their children's education, especially for the continuation of the child's learning to a higher level. This is also consistent with the view that parents' education and the family income is a strong predictor of educational success of children (Yan, 1999, p. 7). In addition, these conditions also have an impact on parent participation in school activities which is also low for the sake of education of their children (Lazar \& Slostad, 1999, p. 208).

Imogiri State Junior High School 3 has the vision, mission, and goals of the school which are clear. To achieve the goals of the school, packaging the learning experience of students in the SBC are compiled and updated the beginning of each new school year. Geographically, Imogiri Junior High School 3 is located in the border area of Bantul and Gunung Kidul District and is on the edge of the highway Bantul-Bake. The quantity and qualifications of teachers and employees are appropriately adequate. Even more, most of teachers are still in their young ages. The school also has the task to organize sports class. However, some students still do not have enough motivation to learn. These conditions show that the education in this school is actually programmed well and supported by sufficient human resources, but the process of education is still needed to be improved for the sake encouraging students' motivation to learn.

There is also condition of the communities in which students live that becomes a particular area holding low-income people who work as a beggar. The communities also have less positive habits, such as watching a video that was not appropriate to the children, the use of HP which are less positive, and also less socially supportive children's education. Some communities even have a habit of marrying their children who have just graduated from junior high school. In addition, there is a place that is less concerned about the school, and even affects the activity of children in junior high school. In society, children live with their environment, have friends on their age, and utilize information and communication media such as watching TV, using the HP or the Internet to communicate. Urie Bronfenbrenner (1989) explained that the neighbors, peers, and the media are parts of children society (Bern, 2004, p. 15).

To examine the implementation of the educational responsibilities undertaken by the family, school, and the community, it was analyzed by using the reference from CoxPettersen (2011, p. 20). it is done by grouping responsibilities carried out separately, sequentially, and shared together. (1) The responsibility of education which is separated at Imogiri Junior High School 3, is presented as follows. Education in the family includes: the culture of work quickly to get a dispensation; instilling the values of honesty, accuracy; encouraging discipline of worship, time, and traveling; practicing the role of the children with the task of helping the housework. Aspects of school education that is separated include: delivering academic content through formal education which is packed in the form of School Based Curriculum (SBC) nationally, local content, as well as self-development, and special coaching classes for students of sport; teaching the role of children through active participation in MSLJ activities, and imparting discipline to children through school disci- 
pline, responsibility and school hygiene class, to use hand phone and ride motorcycle to school. In society, the children get the educational experience from the neighbors in terms of keeping the environment or public facilities through environmental hygiene. (2) The responsibility of education is carried out by the family, school, and community respectively includes three aspects, namely, religion, health, and life as a citizen. Religion and health education begins in the family which is continued at school, but not reported in the community. Education is regarding a life as citizens in school and then continued in the community through activities on August 17 and community service villages along with peers and neighbors. (3) The responsibility of education which is carried out jointly by the family, school, and community include: physical education, social skills, awareness of drugs, and sex education. In terms of aspect of social skills, awareness of drugs and sex education, the children get less education from society. Meanwhile, for education related to nutrition, character education, the use of media, and academic achievements, just carry along by the family and the school.

The above description shows that the pattern of education in Imogiri State Junior High School 3 is composed by the implementation of the education in the family, school, and community that includes neighbors, peers, electronic mass media (television and hand phone) which is either separately, sequentially, or collectively the same. (1) Separately, the family educates children in the aspect of discipline, cultural values, and the roles of the children; the school conducts formal education with academic content of national, local, selfdevelopment, and sports classes which are contained in School Based Curriculum (SBC), the role of students, non-academic achievement, and discipline; while the community, in this case the neighbors and peers teach children to place or maintain public facilities in the environment. (2) Subsequently, in their family, children received religious education and health, which is continued in the school and in the community, while education about life as citizens began to be given at school and continued on through the neighboring community and peers. (3) Along with the family, school, and community take the responsibilities of physical education, social skills, awareness of drugs, and sex education, but for social skills training, drug awareness and sex education, children get bad influence from the neighboring community, peers, and media communication like hand phone. As for the aspect of character education, nutrition, media use, and the achievement can only be conducted jointly by the family and the school.

The quality of education in Imogiri State Junior High School 3 can be grouped into the quality at the level of the individual student and the school system level with the reference of UNESCO $(2005$, p. 1). The individual level of education quality conditions at Imogiri State Junior High School 3 can be precisely described as follows. (1) The school can reduce the students' barriers or difficulties in terms of poverty, social, and academic skills aspects, so that, the students can still enroll the education in the school. (2) The school utilizes and strengthens the knowledge and experience of children in terms of their academic potential, non-academic potential, and personal health to improve their learning. The school can also solve the problem of the students who get negative experiences. (3) The adjustment is done through the educational content of the curriculum reform, the implementation of local content, extracurricular, integration of ICT in learning, and creative curriculum of sports. (4) The school applies various learning processes for example, creative teacher held multimedia learning, a small proportion of teachers use the LCD in learning, tutoring and deepening of the materials and compaction of the day are preserved. However, all of those things are still not optimal to provide local content and multimedia learning support facilities which are still needed to be completed. (5) In order to improve the learning environment, the school eliminates corporal punishment with a fair punishment which sounds more educating, the students are taught not to be worried or anxious in order to build good relationship between teachers and students, the school can also overcome delinquency in class by providing adequate sports fields, while the physical environment can be seen from the well-managed sanitation. However, the security in the school has not physically perfect yet. Thus, it can be interpreted that the quality of education at the individual level Imogiri State Junior High School 3 is quite optimal in the aspect of students 'understanding of the condition, the recognition of 
students' knowledge and experience, and the adjustment of educational content. Meanwhile, for the implementation of various aspects of the learning process and improving the learning environment is still not optimal.

The quality of educational condition at the level of the school system in Imogiri State Junior High School 3 is presented in detail as follows. (1) The school makes rules that can guarantee the rights of students to get education in the form of a support mechanism to the school in the form of 'grants', a statement letter as new students, 'Galawidya' to spur the National Examination, development of the curriculum which involves stakeholders. (2) The policy implemented by school includes: policies to address the problem based on the fairness, according to the rules, do not underestimate, collaboration, documentation; the school maintains load balance tasks of all teachers; provision of school avoids coercion and give dispensation; MSJL program. (3) The school administration and school leadership are implemented by principals supported by teachers, staff, school board, and community classes. However, optimal supports from parents in the administration of sports classes are still low. Besides, the school still continues to remind parents to change their habits that marry his daughter newly after graduated from junior high school. In this case, the school is still on negotiation to build a harmonious relationship with a non-formal educational board. (4) The provision of resources is done through optimization support from the class association for the improvement of learning facilities and payment honorarium, empowering school boards to insufficient human resources, MGMPs empowerment, empowerment of parents as soccer coaches, teachers picket empowerment, and support for Internet network although it is still limited. (5) The school can measure student learning outcomes through daily tests, assignments, remedial programs, enrichment programs, midterms, and final exams which are administered seriously by teachers and schools. Thus, it can be inferred that the quality of education at the level of the school system in Imogiri State Junior High School 3 is quite optimal in the aspect of the creation of the legislative framework, the adoption of good policies, provision of resources, and measurement of student learning outcomes, though the administrative support and leadership is still not optimal.

\section{The Configuration of Education and the Quality of Education in PGRI Junior High School Kasihan}

Socio-economic conditions of most students' parent of Kasihan PGRI Junior High School can be classified into the middle class and even low class because most of them work as labors. Family socio-economic circumstances is weak, therefore, the participation of parents in school activities for their children's education is also low. This is in line with those expressed by Lazar \& Slostad (1999, p. 208) that low-income parents are not able to participate actively involved in the school.

Kasihan PGRI Junior High School has vision, mission, and educational goals which are clear. This school is an inclusive school. Thus, SBC applied by this school is strived to support the education of children with special needs. To attract people and society, PGRI Junior High School develop "The Junior High School plus Life Skills", because of the low academic ability of student. Teacher resources are adequate if it is seen from the qualifications and competence. Although there are some teachers whose qualifications are not relevant, their competencies are still reliable, including serving the children with special needs. School employee resources are still lack quantitatively. Educational facilities are inadequate to support optimal learning process. This school was once known as the school for students moving from other schools, and their students are known by their delinquency. However, the condition at this time is very different, the students are orderly manageable. In connection with the problems with other schools, it was only because of a misunderstanding and can be resolved amicably soon.

Socio-economic condition of the people is in the lower middle class; even more, they are lower than the middle economy class. The area around the school is known as the "red" area in terms of students' delinquency, alcohol, and drugs. Therefore, the School Board is often in coordination with the Police Police District Office and Youth Coordinating Board (Bakopar) in Bantul District to monitor the possibility of influence which can be brought to school. 
To explore the implementation of educational responsibilities undertaken by the family, school, and the community, it was analyzed with reference to the views of CoxPettersen $(2011$, p. 20) in which responsibilities are carried out separately, sequentially, and shared. (1) The responsibility of education that is separated in PGRI Junior High School Kasihan is presented as follows. Education in the family includes: controlling children in watching TV; cultivating hard work, diligent study and regular prayer; instilling the values of prudence, open and honest,; instilling discipline of learning time, play, drive; training the children's role by giving the task of representing the family in village activities, studying, and doing homework. Education in schools include: implementing an inclusive formal education packaged in the School Based Curriculum which covers national, local, personal development, and life skills; training the children's role by participating in student council activities, maintaining the cleanliness and beauty, serving friends and teachers, as well as instilling discipline to obey the time to go to class, wear clothes, and follow the lessons. Education in the community such as children gain experience from peers and neighbors in terms of caring for the environment or public facilities through community service activities in the village. (2) In sequential order, family, school, and community are responsible for children's religious education, health, and life as a citizen. (3) The responsibility of education which is carried out jointly by the family, school, and community only includes aspects of social skills and awareness of the drug. Children get bad influences from the social skills aspect of the neighbors, and the awareness of the drug from neighbors and family, while physical education, character education, sex education, and nutrition is only carried out jointly by the family and the school.

The above description shows that the configuration of education in Kasihan PGRI Junior High School is composed of the implementation of educational responsibilities in the family, school, and community that includes neighbors, peers, electronic mass media (television, mobile phones, and the Internet), which are carried out separately, sequentially, or jointly. (1) Separately, families educate children in using media like watching TV, developing a culture of hard work and regular pray- er; instilling the values of frugality, openness, and honesty; establishing discipline in playing, learning, and driving; and training the role of the children; schools provide formal education to meet the national and local academic content, personal development, life skills and inclusive education, train the role of the student, and instill discipline; whereas communities, neighbors, and peers teach children to maintain a public place or environment through community service activities. (2) Subsequently, the family gives education concerning religion, health, and life as a citizen, which is forwarded further at school and in the community. (3) Concurrently, the family, the school, and the community have the educational responsibilities with regard to social skills and awareness of drug abuse. Yet, the family affects less in raising drug awareness; even neighbors are unfavorable influence to both aspects. As for the aspects of nutrition, physical, character, and sex education, as well as development of academic achievement are conducted jointly by the family and the school.

The quality of education in Imogiri State Junior High School 3 can be categorized into the quality of the individual student level and the school system level referring to the text of UNESCO (2005, p. 1). In detail, the conditions of the quality of education at the individual level in Kasihan PGRI Junior High School are described as follows: (1) The school is able to reduce students' barriers or difficulties to enroll in the school in the aspects of poverty, health, and physical or mental disability. (2) The school strengthens students' knowledge and experience in aspects of disabled academic ability, special talents, more knowledge, and low school motivation; otherwise the school had to work hard to eliminate the delinquency. (3) The school customizes the content of both curricular and extracurricular educations as well as the national and local content according to the conditions of students, schools, and the potential of the region. (4) The school applies various learning process by giving extra lessons to the disabled, integrating character education to the subjects, conducting Achievement Motivation Training (AMT), and using LCD projectors in classes. (5) The school eliminates physical punishment with positive and educative ones and eases students' fears of school by creating a calm atmosphere, yet with inadequate sewerage. Thus, it can be concluded 
that the quality of education at the individual level in Kasihan PGRI Junior High School is considered optimal in aspects of the comprehension of the students' condition, the adjustment of the education content, and the application of various learning processes, while aspects of the recognition for students' knowledge and experience and the improvement of the learning environment are not yet optimal.

The quality of education at the school system level in Kasihan PGRI Junior High School is presented in the following descriptions: (1) The rules are made by school to ensure students' rights for education in the form of a synergistic cooperation in the fulfillment of teachers' teaching loads, to receive disabled students, to selectively receive a transfer student, and to recruit teachers determined by school foundations. (2) The school policy reaches all the educational activities of the school, in terms of cross-subsidies and efficiency of school operational costs (BOS), uniforms, supporting books, health center, and school participation in social activities. (3) The development of administrative support and leadership is sought for schools to exist, through the socialization of plus-life-skills junior high school, the leadership by a competent teacher, the networking with many elementary schools, and the collaborations with stakeholders. (4) The school has not been able to provide resources in the form of sufficient funds, teachers, staffs, and facilities. (5) The school measures student learning outcomes through daily tests, midterms, and final exams which are administered seriously by teachers and the school. Thus, it means that the quality of education at the school system level in Kasihan PGRI Junior High School is considered optimal in the aspect of the creation of the legislative framework, the adoption of good policies, the development of administrative support and leadership, and the measurement of learning outcomes, but not really optimal in the aspect of resource provision.

\section{The Link between the Configuration of Education with the Quality of Education}

The configuration of education in Kretek State Junior High School 2 suggests that there are nine aspects of education conducted jointly between the family and the school. Only four aspects of education being conducted jointly by the family, school and community give positive influences, while the other two aspects of the quality of education cannot be optimally achieved by the school. The configuration of education in Imogiri State Junior High School 3 illustrates that there are eight aspects of education conducted jointly between the family and the school. There are only 4 aspects of education which is being conducted jointly by the family, school and community, and there is a negative effect on some aspects of education. Meanwhile, there are three aspects of the quality of education which cannot be achieved optimally by the school. The configuration of education in Kasihan PGRI Junior High School shows that there are seven aspects of education which are carried out jointly between the family and the school. There are only two aspects of education which is being conducted jointly by the family, school, and community, and there is a negative effect on some aspects of education. Meanwhile, there are three aspects of the quality of education cannot be achieved optimally by the school.

The pattern of the configurations of education generated by the variation of implementation of educational responsibilities in the family, at school, and in society, which are made separately, sequentially, or jointly is related to the achievement of quality education in schools both at the level of individual students and the school system. Schools which conducted more configurations of educational responsibilities together are able to achieve optimal quality of education than do the schools which conduct fewer configurations of educational responsibilities. In short, the more the responsibilities of education performed together, the more optimal the quality of education in the schools. The schools which carry out configuration educational responsibilities with no negative effect from the community are able to achieve more optimal quality of education than do the schools which carried out responsibilities with the negative influence of society.

Of various configuration patterns of education and the quality of education from all three schools, the pattern configuration in Kretek State Junior High School 2 is the optimal configuration pattern of education among families, schools, and communities that impact on the optimal quality of education with the following characteristics: (1) the family, school, and society consistently perform educational responsibilities that are carried out 
separately, sequentially, and jointly (shared) and without negative influence; (2) separately, the family do the educational responsibilities on discipline, culture, values, roles; schools conduct education on academic content, discipline, and the role of the student, and the community gives the experience on maintaining the place or public facilities; (3) respectively, family, school, and community provide experiences to children about religion, health, and life as a citizen; and (4) together, families, schools, and communities undertake responsibility on nutritional education, social skills, awareness against drug abuse, the use of media, academic achievement, non-academic achievement, and physical, character, and sex education.

\section{CONCLUSIONS}

The configuration pattern of education in three junior high schools in Bantul was formed by the variations in the implementation of educational responsibilities of family, school, and community (neighbors, peers, and electronic media) which are carried out separately, sequentially, or jointly. Separately, the family educates students about discipline, culture, values, and the role of the children; schools educate them about aspects of national and local academic content, inclusive education, personal development, life skills, discipline, and the role of the student; community provides educational experience about the maintenance of the environment or public facilities. Sequentially, family, and community educate students about religion, health, and life as a citizen, meanwhile jointly they educate students about social skills, awareness of drug abuse, and physical and sex education. The quality of education at three secondary schools in Bantul district varies both at the level of individual students and at the school system level. At the individual level, the schools are optimal in understanding the students' condition and making the relevance of the content of education, but are less optimal in recognizing the knowledge and experience of students, implementing a variety of learning processes, and improving the learning environment. Meanwhile, at the level of the school system, the schools are optimal in creating a framework of legislation, implementing good policies, and measure learning outcomes, but are less optimal in building administrative support and leadership as well as providing sufficient re- sources. The configuration pattern of education among families, schools, and communities are related to the quality of education in schools at the level of the individual student and at the school system level. The more aspects of educational responsibilities undertaken together, the more optimal the quality of education in schools; and the presence or absence of a negative effect in the aspect of education is related to the quality of education in schools. Configuration pattern of education among families, schools, and communities that impact on the quality of higher education has the characteristic that each institution consistently performs educational responsibilities that are separate, sequential, or shared with no negative effect on the educational aspect.

Referring to the discussions and conclusions of this study, there are several suggestions to be put forward, namely: (1) primary school education cannot be separated from the responsibility of parents and families, so that parents should seriously oversee the education of children in schools and control the influences of society. (2) Schools, in an effort to achieve a high quality education should enhance the learning environment more conducive, especially with regard to safety and health, and be much more sensitive to the potential of children inherited from the family, to the education outcomes of the family, and also to the conditions or social influences from the environment. (3) There should be effective lines of communication between parents, the school, and the community, as well as schools and school boards, to establish a common understanding and commitment that children's education should really conducted by all (education by all).

\section{REFERENCES}

Anonim. (2010). Di kota pelajar, sepuluh ribu siswa SMP tak lulus UN. Tempo Interaktif. Tempo Interaktif.

Anonim. (2011). Indeks pendidikan Indonesia menurun. Kompas.Com. Retrieved from https://edukasi.kompas.com/read/2011/0 3/02/18555569/Indeks.

Pendidikan.Indonesia.Menurun

Arcaro, J. S. (1995). Quality in education: an implementation handbook. Florida: St. Lucie Press.

Aspin, D. N., Champan, J. D., \& Wilkinson, 
V. R. (1994). Quality schooling: a pragmatic approach to some current problems, topic, and issues. London: Cussel.

Bern, R. M. (2004). Child, family, school, community: Socialization and support (6th ed.). Australia: Thomson Learning, Inc.

Cox-Pettersen. (2011). Educational partnerships: Connecting school, families, and the community. Los Angeles: Sage Publication, Inc.

Danim, S. (2006). Agenda pembaharuan sistem pendidikan. Yogyakarta: Pustaka Pelajar.

Decker, L. E., \& Decker, V. A. (2003). Home, school, and community partnerships. Lanham: The Scarecrow Press, Inc.

Epstein, J. L., \& Voorhis, F. L. V. (2010). Professional school counseling. Retrieved May 25, 2012, from www.schoolcounselor.org

Goodlad, J. I. (1984). A place called school: Prospect for the future. New York: McGraw Hill Book Company.

Guellali, C. (2008). A quality framework for providers of further education in the German context. International Journal of Educational Management, 22(2), 129-134.

Hurlock, E. B. (1991). Psikologi perkembangan: Suatu pendekatan sepanjang rentang kehidupan. (Istiwidayanti, Trans.). Jakarta: Erlangga.

Lazar, A., \& Slostad, F. (1999). How to overcome obstacles to parent-teacher partnerships. The Clearing House ( ProQuest Education Journals), 72(4), 206.

MONE. (2002). Manajemen peningkatan mutu berbasis sekolah: Konsep dasar. Jakarta: Ditjen Dikdasmen.

MONE. (2007). Pendidikan dan pelatihan: Manajemen hubungan sekolah dan masyarakat dalam pemberdayaan masyarakat. Jakarta: Ditnaga Ditjen PMPTK.

Pigozzi, M. J. (2004). Quality education and HIV/AIDS. Paris: UNESCO 7, place de Fontenoy. 75352 - Paris 07 SP.
Prasetyo, A. (2010). Pendapat guru: Masa memilih sekolah. Kedaulatan Rakyat, 7.

Presiden Republik Indonesia. Instruksi Presiden RI Nomor 1 Tahun 1994 tentang Pelaksanaan wajib belajar pendidikan dasar (1994).

Presiden Republik Indonesia. Peraturan Pemerintah Republik Indonesia Nomor 19 Tahun 2005 tentang Standar Nasional Pendidikan (2005).

Presiden Republik Indonesia. Instruksi Presiden RI Nomor 5 Tahun 2006 tentang Gerakan nasional percepatan penuntasan wajib belajar pendidikan dasar sembilan tahun dan pemberantasan buta aksara. (2006)

Rifai, V., \& Murni, S. (2010). Education management: Analisis teori dan praktik. Jakarta: Rajawali Pers.

Syafaruddin. (2002). Majamemen mutu terpadu dalam pendidikan: Konsep, strategi, dan aplikasi. Jakarta: Grasindo.

The World Bank. (2005). Indonesia policy brief - ideas for the future: Improving education quality.

Tirtarahardja, U., \& Sulo, S. L. L. (2005). Pengantar pendidikan (Revisi). Jakarta: PT Rineka Cipta.

Tjiptono, F., \& Diana, A. (2000). Total quality management. Yogyakarta: Andi.

UNESCO. (2005). Contributing to more sustainable future: quality education, life skill and education for sustainable development. In Division for the Promotion of Quality Education Education Sector 7. place de Fontenoy 75352 Paris 07 SP France. ED/PEQ/IQL/2005/PI/H/2. Retrieved from http://www.unesco.org/education

Yan, W. (1999). Successful African American students: The role of parental involvement. The Journal of Negro Education (ProQuest Education), 68(1).

Zamroni. (2002). Paradigma pembangunan pendidikan nasional dalam mewujudkan peradaban bangsa; Pendidikan untuk masyarakat Indonesia baru. (I. Syarief \& D. Murtadlo, Eds.). Jakarta: Grasindo.

Zuchdi, D. (2009). Pendidikan karakter: Grand design dan nilai-nilai target. Yogyakarta: UNY Press. 